\section{Foliar Sprays of Flurprimidol, Paclobutrazol, and Uniconazole Suppress Height of Seed- propagated New Guinea Impatiens}

\author{
Christopher J. Currey ${ }^{1,4}$, Nicholas J. Flax ${ }^{2,3}$, and Kellie J. Walters ${ }^{3}$
}

ADDITIONAL INDEX WORDs. plant growth retardant, plant growth regulator, ancymidol, chlormequat chloride, daminozide, Impatiens bawkeri

SuMmary. Our objective was to quantify the efficacy of foliar plant growth retardant applications on plant height and time to flower of seed-propagated new guinea impatiens (Impatiens bawkeri) produced in packs and flats. 'Divine Cherry Red', 'Divine Scarlet Bronze Leaf', and 'Divine White Blush' seedlings were planted in 1801cell packs. Seven days after planting, deionized water (control) or solutions containing ancymidol (15 to $\left.60 \mathrm{mg} \cdot \mathrm{L}^{-1}\right)$, chlormequat chloride $\left(750\right.$ to $\left.3000 \mathrm{mg} \cdot \mathrm{L}^{-1}\right)$, daminozide (1250 to $\left.5000 \mathrm{mg} \cdot \mathrm{L}^{-1}\right)$, ethephon $\left(250\right.$ to $\left.1000 \mathrm{mg} \cdot \mathrm{L}^{-1}\right)$, flurprimidol (10 to $40 \mathrm{mg} \cdot \mathrm{L}^{-1}$ ), paclobutrazol $\left(10\right.$ to $\left.40 \mathrm{mg} \cdot \mathrm{L}^{-1}\right)$, or uniconazole $\left(5\right.$ to $20 \mathrm{mg} \cdot \mathrm{L}^{-1}$ ) were applied to seedlings. A second experiment was performed with the same cultivars quantifying the growth and development in response to a broader range of flurprimidol or paclobutrazol $\left(5\right.$ to $\left.40 \mathrm{mg} \cdot \mathrm{L}^{-1}\right)$ or uniconazole $\left(2.5\right.$ to $\left.20 \mathrm{mg} \cdot \mathrm{L}^{-1}\right)$ sprays. Plant height was measured 7 weeks after planting. For Expt. 1, ancymidol, chlormequat chloride, and daminozide had little to no impact on stem elongation. However, flurprimidol, paclobutrazol, and uniconazole suppressed height at flowering of all three cultivars. In Expt. 2, plant height with concentrations flurprimidol, paclobutrazol, or uniconazole up to 27 to 30,20 to 30 , or 4 to $5 \mathrm{mg} \cdot \mathrm{L}^{-1}$, respectively, depending on the cultivar. Five to $20 \mathrm{mg} \cdot \mathrm{L}^{-1}$ flurprimidol or paclobutrazol, or < $2.5 \mathrm{mg} \cdot \mathrm{L}^{-1}$ uniconazole may be used to control stem elongation of seed-propagated new guinea impatiens for production in flats.

$\mathrm{B}$ edding impatiens (Impatiens walleriana) are one of the most popular annual bedding plants. They are used for their ability to thrive under a wide variety of site conditions, including shade (Armitage, 2001; Still, 1993). Beginning in 2011, impatiens downy mildew (Plasmopara obducens) has been identified in landscapes across North America (Caitlin, 2013). As symptoms of impatiens downy mildew develop in bedding impatiens, leaves and flowers senesce prematurely and, therefore, reduce landscape appeal (Warfield, 2012). The increased range and incidence of impatiens downy mildew has caused landscapers and consumers to select alternative species to use where bedding impatiens were

Department of Horticulture, Iowa State University, Ames, IA 50011

The authors would like to thank Peter Lawlor for greenhouse assistance, Steven Mahoney for greenhouse supplies, Fine Americas, OHP, and SePRO for plant growth regulators, and Wagner Greenhouses for plant material. The use of trade names in this publication does not imply endorsement by Iowa State University of products named nor criticism of similar ones not mentioned.

${ }^{1}$ Assistant professor

${ }^{2}$ Former undergraduate research assistant

${ }^{3}$ Graduate research assistant

${ }^{4}$ Corresponding author. E-mail: ccurrey@iastate.edu. previously planted (Caitlin, 2012). New guinea impatiens are tropical annuals that grow well and flower in shade with a wide range of flower and foliage colors (Armitage, 2001; Still, 1993; Whealy, 1995). Furthermore, they are resistant to impatiens downy mildew (Caitlin, 2013). Together, these attributes give new guinea impatiens the potential to replace bedding impatiens in the landscape.

New guinea impatiens are commonly propagated vegetatively using stem tip cuttings and finished in containers with a higher retail value, such as 4- or 5-inch-diameter containers or hanging baskets (Dole and Wilkins, 2005; Nau, 2011). Producing flats of vegetatively propagated new guinea impatiens would not be feasible due to the size of the starting material relative to planting density in a flat and the cost of production. The modest price per plant that contributes to the consumer appeal of bedding impatiens in flats makes production of flats with vegetatively propagated new guinea impatiens uneconomical. The development of $F_{1}$ hybrid seedpropagated new guinea impatiens provides an opportunity for lower cost propagules that could be produced economically in flats. However, one challenge with producing plants in flats is controlling growth to produce plants that are attractive and appropriately sized for the container.

Vegetatively propagated new guinea impatiens do not routinely require plant growth retardants (PGRs) in production (Dole and Wilkins, 2005). One reason is that they are usually grown in containers that are 4 inches or greater in diameter, and plants in these containers generally require less growth regulation to produce an appropriately sized plant compared with plants produced in smaller containers such as packs and flats. Plant growth can be regulated and influenced in vegetatively propagated new guinea impatiens by irrigation and mineral nutrition levels (Haver and Schuch, 1996). Although modifying crop culture may result in an acceptable level of growth control for vegetatively propagated new guinea impatiens grown in larger containers, it may not provide enough control to suppress new guinea impatiens height produced in flats.

While PGRs are useful in suppressing height of containerized greenhouse flowering crops, we have found no published recommendations for applying PGRs to control growth of seed-propagated new guinea impatiens. The objective of this research was to quantify the efficacy of foliar applications of PGRs for production of seed-propagated new guinea impatiens in flats. This was accomplished in a series of two experiments. In the first experiment several cultivars were treated with a wide range of active

\begin{tabular}{llll}
\hline $\begin{array}{l}\text { Units } \\
\begin{array}{l}\text { To convert U.S. to SI, } \\
\text { multiply by }\end{array}\end{array}$ & U.S. unit & SI unit & $\begin{array}{l}\text { To convert SI to U.S., } \\
\text { multiply by }\end{array}$ \\
\hline 0.0929 & $\mathrm{ft}^{2}$ & $\mathrm{~m}^{2}$ & 10.7639 \\
2.54 & inch(es) & $\mathrm{cm}$ & 0.3937 \\
16.3871 & inch & $\mathrm{cm}^{3}$ & 0.0610 \\
1 & $\mathrm{ppm}$ & $\mathrm{mg} \cdot \mathrm{L}^{-1}$ & 1 \\
0.1019 & $\mathrm{qt} / 100 \mathrm{ft}^{2}$ & $\mathrm{~L} \cdot \mathrm{m}^{-2}$ & 9.8170 \\
$\left({ }^{\circ} \mathrm{F}-32\right) \div 1.8$ & ${ }^{\circ} \mathrm{F}$ & ${ }^{\circ} \mathrm{C}$ & $\left({ }^{\circ} \mathrm{C} \times 1.8\right)+32$
\end{tabular}


ingredients and concentrations. In the second experiment, a broader range of concentrations of the most effective active ingredients from the first experiment were used to model the responses and generate recommendations.

\section{Materials and methods}

EXPERIMENT 1. 'Divine Cherry Red', 'Divine Scarlet Bronze Leaf', and 'Divine White Blush' new guinea impatiens seedlings in 288-cell trays were received from a commercial plug producer (Wagner Greenhouses, Minneapolis, MN). Seedlings were individually planted in 1801-cell packs [3.11 inches length and width, 2.25 inches height, 17.7 inch $^{3}$ volume (STI-1801; T.O. Plastics, Clearwater, MN)] filled with a commercial soilless substrate comprised of canadian sphagnum peatmoss, and perlite amended with dolomitic limestone, starter nutrient charge, and surfactant (Sunshine Mix \# 1; Sun Gro Horticulture, Agawam, MA) on 4 Sept. 2013. Plants were grown in a glass-glazed greenhouse at Iowa State University, Ames, IA (lat. $42^{\circ} \mathrm{N}$ ) with fog cooling, radiant hot-water floor and perimeter heating, and retractable shade curtains controlled by an environmental computer (Titan; ARGUS Control Systems, Surrey, BC, Canada). The day and night greenhouse air temperature set points were $23 \pm 1{ }^{\circ} \mathrm{C}$ and $19 \pm 1^{\circ} \mathrm{C}$, respectively, with natural day lengths and ambient photosynthetic photon flux $(P P F)$. When the majority of plants required irrigation, as judged by the color of the substrate surface and weight of flats, flats were irrigated until leaching was visible to reduce any excess salts. Plants were irrigated alternating between tap water and water supplemented with a blend of water-soluble fertilizers $[50$ and $100 \mathrm{mg} \cdot \mathrm{L}^{-1} \mathrm{~N}$ provided from $21 \mathrm{~N}-$ $2.2 \mathrm{P}-16.6 \mathrm{~K}$ and $15 \mathrm{~N}-2.2 \mathrm{P}-12.5 \mathrm{~K}$, respectively (Everris NA, Marysville, $\mathrm{OH})$ ] to provide the following (in $\left.\mathrm{mg} \cdot \mathrm{L}^{-1}\right)$ : 150 nitrogen, 8.6 phosphorous, 92.2 potassium, 33.3 calcium, 13.3 magnesium, 0.75 iron, 0.4 manganese, 0.4 zinc, 0.2 copper, 0.2 boron, and 0.5 molybdenum.

Seven days after planting, nine individual plants of each cultivar were treated with foliar sprays of deionized water, ancymidol [20, 40, or $80 \mathrm{mg} \cdot \mathrm{L}^{-1}$ (Abide; Fine Americas,
Walnut Creek, CA)], chlormequat chloride $\left[750,1500\right.$, or $3000 \mathrm{mg} \cdot \mathrm{L}^{-1}$ (Cycocel; OHP, Mainland, PA)], daminozide $[1250,2500$, or 5000 $\mathrm{mg} \cdot \mathrm{L}^{-1}$ (Dazide, Fine Americas)], ethephon $\left[250,500\right.$, or $1000 \mathrm{mg} \cdot \mathrm{L}^{-1}$ (Collate, Fine Americas)], flurprimidol $\left[10,20\right.$, or $40 \mathrm{mg} \cdot \mathrm{L}^{-1}$ (Topflor; SePro, Carmel, IN)], paclobutrazol $\left[10,20\right.$, or $40 \mathrm{mg} \cdot \mathrm{L}^{-1}$ (Piccolo; Fine Americas) $]$, or uniconazole $[5,10$, or $20 \mathrm{mg} \cdot \mathrm{L}^{-1}$ (Concise; Fine Americas)] applied at a rate of $2 \mathrm{qt} / 100 \mathrm{ft}^{2}$ with a hand sprayer. Following PGR applications, all treated plants for a single cultivar were randomized and placed back into flats.

Plant height from the substrate surface to the top of the plant was measured on the date the first flower opened. Time to flower from planting was calculated. The experiment was conducted in a completely randomized design with nine replications (individual plants) for each treatment. Analyses of variance and pairwise comparisons between treatments using Tukey's honestly significant difference test at $P \leq 0.05$ were performed using SPSS (version 21.0 ; IBM Corp., Armonk, NY).

EXPERIMENT 2. The same cultivars were planted as described in Expt. 1 on 12 May 2014. Seven days later, plants were sprayed with solutions containing $0,5,10,20$, or $40 \mathrm{mg} \cdot \mathrm{L}^{-1}$ flurprimidol (Topflor, SePro) or paclobutrazol (Piccolo, Fine Americas) or $0,2.5,5,10$, or $20 \mathrm{mg} \cdot \mathrm{L}^{-1}$ uniconazole (Concise, Fine Americas). Seven weeks after planting the height was recorded as in Expt. 1. There were three replications (an entire flat with 18 individual plants) per concentration per chemical for each cultivar. For each cultivar and chemical, data were modeled with an exponential decay model $\left(y=y_{0}+a e^{-b x}\right)$ and regression analyses were performed using Sigma Plot (version 12.5; Systat Software, San Jose, CA). In addition, the above equation was solved for the concentration of active ingredients, where suppression of plant height was $95 \%$ of maximum suppression for each cultivar and active ingredient to determine the point of saturation for each chemical.

\section{Results}

Experiment 1. The effectiveness of PGRs in suppressing stem elongation of the three new guinea impatiens cultivars differed among active ingredients. For 'Divine Cherry Red' there were no differences between untreated plants and plants treated with any concentration of ancymidol, chlormequat chloride, daminozide, ethephon, or $10 \mathrm{mg} \cdot \mathrm{L}^{-1}$ flurprimidol (Table 1). 'Divine Cherry Red' plants treated with 20 to $40 \mathrm{mg} \cdot \mathrm{L}^{-1}$ flurprimidol, 10 to $40 \mathrm{mg} \cdot \mathrm{L}^{-1}$ paclobutrazol, or 5 to $20 \mathrm{mg} \cdot \mathrm{L}^{-1}$ uniconazole were 3.2 to $3.8 \mathrm{~cm}, 3.1$ to $4.1 \mathrm{~cm}$, or 4.0 to $4.3 \mathrm{~cm}$ shorter, respectively, than untreated plants. A similar trend in effective active ingredients was observed for 'Divine Scarlet Bronze Leaf'. Applying up to $40 \mathrm{mg} \cdot \mathrm{L}^{-1}$ flurprimidol or paclobutrazol or $20 \mathrm{mg} \cdot \mathrm{L}^{-1}$ uniconazole resulted in plants that were up to $4.1,4.2$, or $4.2 \mathrm{~cm}$ shorter, respectively, than untreated plants. While chlormequat chloride and daminozide had no effect on height of 'Divine White Blush', $40 \mathrm{mg} \cdot \mathrm{L}^{-1}$ ancymidol or $1000 \mathrm{mg} \cdot \mathrm{L}^{-1}$ ethephon suppressed height by 2.6 or $2.4 \mathrm{~cm}$, respectively, compared with untreated plants. All concentrations of flurprimidol, paclobutrazol, and uniconazole resulted in plants that were 3.2 to $5.8 \mathrm{~cm}, 5.5$ to $5.7 \mathrm{~cm}$, or 5.4 to $5.6 \mathrm{~cm}$ shorter, respectively, than untreated plants.

Variation in the effect of chemical applications on time to flower was observed among cultivars (Table 1 ). When $500 \mathrm{mg} \cdot \mathrm{L}^{-1}$ ethephon or 10 or $20 \mathrm{mg} \cdot \mathrm{L}^{-1}$ uniconazole were applied to 'Divine Cherry Red' flowering was delayed by 19,24 , or $28 \mathrm{~d}$, respectively, compared with untreated plants. 'Divine Scarlet Bronze Leaf' treated with the 500 to $1000 \mathrm{mg} \cdot \mathrm{L}^{-1}$ ethephon or the highest concentrations of flurprimidol, paclobutrazol, or uniconazole flowered 18 to 23,16 , 19 , or 18 d later, respectively, than untreated plants. When $40 \mathrm{mg} \cdot \mathrm{L}^{-1}$ flurprimidol or paclobutrazol or 10 to $20 \mathrm{mg} \cdot \mathrm{L}^{-1}$ uniconazole was applied to 'Divine White Blush' new guinea impatiens, flowering was 19, 27, or 14 to $31 \mathrm{~d}$ later, respectively, than untreated plants.

Phytotoxicity was observed for select chemicals on certain cultivars. Leaves turned chlorotic on some 'Divine White Blush' plants treated with chlormequat chloride. For all cultivars, the highest concentrations of flurprimidol, paclobutrazol, and 
Table 1. Plant height and time to flower of 'Divine Cherry Red', 'Divine Scarlet Bronze Leaf', and 'Divine White Blush' new guinea impatiens treated with foliar spray applications of water or plant growth retardant solutions $7 \mathrm{~d}$ after planting seedlings individually into 1801 -cell packs (Expt. 1).

\begin{tabular}{|c|c|c|c|c|c|c|c|}
\hline \multirow[b]{3}{*}{ Chemical } & \multirow[b]{3}{*}{$\begin{array}{c}\text { Concn } \\
\left(\mathrm{mg} \cdot \mathrm{L}^{-1}\right)^{\mathrm{z}}\end{array}$} & \multicolumn{6}{|c|}{ Cultivar } \\
\hline & & \multicolumn{2}{|c|}{ Divine Cherry Red } & \multicolumn{2}{|c|}{ Divine Scarlet Bronze Leaf } & \multicolumn{2}{|c|}{ Divine White Blush } \\
\hline & & Height $(\mathrm{cm})^{\mathrm{z}}$ & $\begin{array}{c}\text { Time to } \\
\text { flower }(d)\end{array}$ & Height $(\mathrm{cm})$ & $\begin{array}{c}\text { Time to } \\
\text { flower }(\mathrm{d})\end{array}$ & Height $(\mathrm{cm})$ & $\begin{array}{l}\text { Time to } \\
\text { flower }(\mathrm{d}) \\
\end{array}$ \\
\hline Water & - & $10.8 \mathrm{a}-\mathrm{c}^{\mathrm{y}}$ & $48 \mathrm{de}$ & $13.9 \mathrm{ab}$ & 41 ef & $13.4 \mathrm{ab}$ & 49 e \\
\hline Ancymidol & 20 & $10.0 \mathrm{~b}-\mathrm{d}$ & $50 \mathrm{de}$ & $14.5 \mathrm{ab}$ & $47 \mathrm{~b}-\mathrm{f}$ & $12.9 \mathrm{a}-\mathrm{c}$ & $53 \mathrm{de}$ \\
\hline Ancymidol & 40 & $9.8 \mathrm{~b}-\mathrm{d}$ & $51 \mathrm{de}$ & $14.1 \mathrm{ab}$ & $44 \mathrm{~b}-\mathrm{f}$ & $10.9 \mathrm{~cd}$ & $50 \mathrm{e}$ \\
\hline Chlormequat & 1,500 & $10.8 \mathrm{a}-\mathrm{c}$ & 48 de & $12.9 \mathrm{~b}-\mathrm{d}$ & 40 ef & $14.1 \mathrm{a}$ & $49 \mathrm{e}$ \\
\hline Chlormequat & 3,000 & $11.8 \mathrm{ab}$ & $47 \mathrm{de}$ & $14.7 \mathrm{ab}$ & $39 \mathrm{f}$ & $13.2 \mathrm{ab}$ & $51 \mathrm{e}$ \\
\hline Daminozide & 1,250 & $11.1 \mathrm{a}-\mathrm{c}$ & $43 \mathrm{e}$ & $14.3 \mathrm{ab}$ & 41 ef & $13.7 \mathrm{a}$ & $54 \mathrm{de}$ \\
\hline Daminozide & 2,500 & $12.8 \mathrm{a}$ & $49 \mathrm{de}$ & $14.5 \mathrm{ab}$ & $46 \mathrm{~b}-\mathrm{f}$ & $12.3 \mathrm{a}-\mathrm{d}$ & $52 \mathrm{de}$ \\
\hline Daminozide & 5,000 & $11.8 \mathrm{ab}$ & $48 \mathrm{de}$ & $14.7 \mathrm{ab}$ & $44 c-f$ & $12.2 \mathrm{a}-\mathrm{d}$ & $51 \mathrm{e}$ \\
\hline Ethephon & 250 & $11.3 \mathrm{a}-\mathrm{c}$ & $50 \mathrm{de}$ & $16.0 \mathrm{a}$ & $43 \mathrm{~d}-\mathrm{f}$ & $13.3 \mathrm{ab}$ & $53 \mathrm{de}$ \\
\hline Flurprimidol & 20 & $7.6 \mathrm{~d}-\mathrm{g}$ & $53 \mathrm{c}-\mathrm{e}$ & $10.4 \mathrm{de}$ & $50 \mathrm{a}-\mathrm{f}$ & 8.4 ef & $57 \mathrm{c}-\mathrm{e}$ \\
\hline Flurprimidol & 40 & $7.0 \mathrm{e}-\mathrm{g}$ & $62 \mathrm{a}-\mathrm{d}$ & $9.8 \mathrm{e}$ & $57 \mathrm{a}-\mathrm{d}$ & $7.6 \mathrm{f}$ & 68 bc \\
\hline Paclobutrazol & 10 & $7.7 \mathrm{~d}-\mathrm{g}$ & $51 \mathrm{c}-\mathrm{e}$ & $10.2 \mathrm{de}$ & $55 \mathrm{a}-\mathrm{f}$ & $7.9 \mathrm{f}$ & $54 \mathrm{de}$ \\
\hline Paclobutrazol & 20 & $7.7 \mathrm{~d}-\mathrm{g}$ & $52 \mathrm{c}-\mathrm{e}$ & $10.8 \mathrm{c}-\mathrm{e}$ & $55 \mathrm{a}-\mathrm{e}$ & $7.3 \mathrm{f}$ & $59 \mathrm{c}-\mathrm{e}$ \\
\hline Paclobutrazol & 40 & $6.7 \mathrm{fg}$ & $56 \mathrm{~b}-\mathrm{e}$ & $9.7 \mathrm{e}$ & $60 \mathrm{ab}$ & $7.7 \mathrm{f}$ & $76 \mathrm{ab}$ \\
\hline Uniconazole & 5 & $6.8 \mathrm{fg}$ & $56 \mathrm{~b}-\mathrm{e}$ & $9.0 \mathrm{e}$ & $54 \mathrm{a}-\mathrm{f}$ & $7.8 \mathrm{f}$ & $57 \mathrm{c}-\mathrm{e}$ \\
\hline Uniconazole & 10 & $5.6 \mathrm{~g}$ & $72 \mathrm{ab}$ & $9.8 \mathrm{e}$ & $51 \mathrm{a}-\mathrm{f}$ & $8.0 \mathrm{ef}$ & $63 \mathrm{~cd}$ \\
\hline Uniconazole & 20 & $6.5 \mathrm{fg}$ & $76 \mathrm{a}$ & $9.7 \mathrm{e}$ & $59 \mathrm{a}-\mathrm{c}$ & $7.8 \mathrm{f}$ & $80 \mathrm{a}$ \\
\hline Significance & & $* * * x$ & $\star * *$ & $* * *$ & $* * *$ & $\star * *$ & $\star * *$ \\
\hline
\end{tabular}

${ }^{\mathrm{z}} \mathrm{l} \mathrm{mg} \cdot \mathrm{L}^{-1}=1 \mathrm{ppm}, \mathrm{l} \mathrm{cm}=0.3937$ inch.

${ }^{y}$ Within-column means followed by different letters are significantly different by Tukey's honestly significant difference test at $P \leq 0.05$. $x * * *$ Significant at $P \leq 0.001$.

uniconazole produced commercially unacceptable plants.

EXPERIMENT 2. The effect of PGR application on height of new guinea impatiens varied with cultivar, active ingredient, and concentration (Fig. 1). Increasing flurprimidol and paclobutrazol concentrations from 0 to $20 \mathrm{mg} \cdot \mathrm{L}^{-1}$ resulted in 'Divine Cherry Red' plants that were 8.0 and $8.6 \mathrm{~cm}$ shorter, respectively, than untreated plants. 'Divine Cherry Red' plant height was 8.5 to $10.5 \mathrm{~cm}$ shorter than untreated plants when 2.5 to $20 \mathrm{mg} \cdot \mathrm{L}^{-1}$ uniconazole was applied, respectively. Using the regression equation modeled for ' $\mathrm{Di}$ vine Cherry Red' and each active ingredient, the points of saturated responses to flurprimidol, paclobutrazol, and uniconazole were 30,30 , and $5 \mathrm{mg} \cdot \mathrm{L}^{-1}$, respectively. The height of 'Divine Scarlet Bronze Leaf' plants treated with 5 to $40 \mathrm{mg} \cdot \mathrm{L}^{-1}$ flurprimidol or paclobutrazol or 2.5 to $20 \mathrm{mg} \cdot \mathrm{L}^{-1}$ uniconazole were $12 \%$ to $58 \%(6.3$ to $13.0 \mathrm{~cm}), 8 \%$ to $53 \%$ (5.7 to $12.4 \mathrm{~cm}$ ), or $48 \%$ to $63 \%$ (11.5 to $13.9 \mathrm{~cm}$ ) shorter, respectively, than untreated plants. For 'Divine Scarlet Bronze Leaf', the effectiveness of flurprimidol, paclobutrazol, and uniconazole was saturated at 27, 23, and $4 \mathrm{mg} \cdot \mathrm{L}^{-1}$, respectively. Untreated 'Divine White Blush' plants were $16.9 \mathrm{~cm}$. The height of 'Divine White Blush' plants treated with 5 to $40 \mathrm{mg} \cdot \mathrm{L}^{-1}$ flurprimidol or paclobutrazol or 2.5 to $20 \mathrm{mg} \cdot \mathrm{L}^{-1}$ uniconazole were $18 \%$ to $60 \%(4.7$ to $11.0 \mathrm{~cm})$, $25 \%$ to $58 \%(5.8$ to $10.7 \mathrm{~cm})$, or $50 \%$ to $66 \%(9.6$ to $11.9 \mathrm{~cm})$ shorter, respectively, than untreated plants. For 'Divine White Blush' the points of saturation with respect to height control for flurprimidol, paclobutrazol, and uniconazole were 29, 20, and $5 \mathrm{mg} \cdot \mathrm{L}^{-1}$, respectively.

The time to flower for each treatment was not quantified in the second experiment and all data were taken 7 weeks after planting. Although not measured, the flowering of 'Divine Cherry Red', 'Divine Scarlet Bronze Leaf', and 'Divine White Blush' was delayed when the highest concentrations of flurprimidol, paclobutrazol, and uniconazole were applied.

No foliar chlorosis was observed for treatments applied in Expt. 2. However, similar to Expt. 1, the size of 'Divine Cherry Red', 'Divine Scarlet Bronze Leaf', and 'Divine White Blush' treated with the highest concentrations of flurprimidol, paclobutrazol, and uniconazole appeared commercially unacceptable (Figs. 2-4).

\section{Discussion}

There are several reports on suppressing height of vegetatively propagated new guinea impatiens using PGRs (Keever and Foster, 1991; McKnight and Klingaman, 1990; Pasutti and Weigle, 1980; Whipker et al., 2004a, 2004b). Our data on the effectiveness of ancymidol, chlormequat chloride, and daminozide in suppressing height are similar to those reported by Pasutti and Weigle (1980). Pasutti and Weigle (1980) quantified the effect ancymidol, 


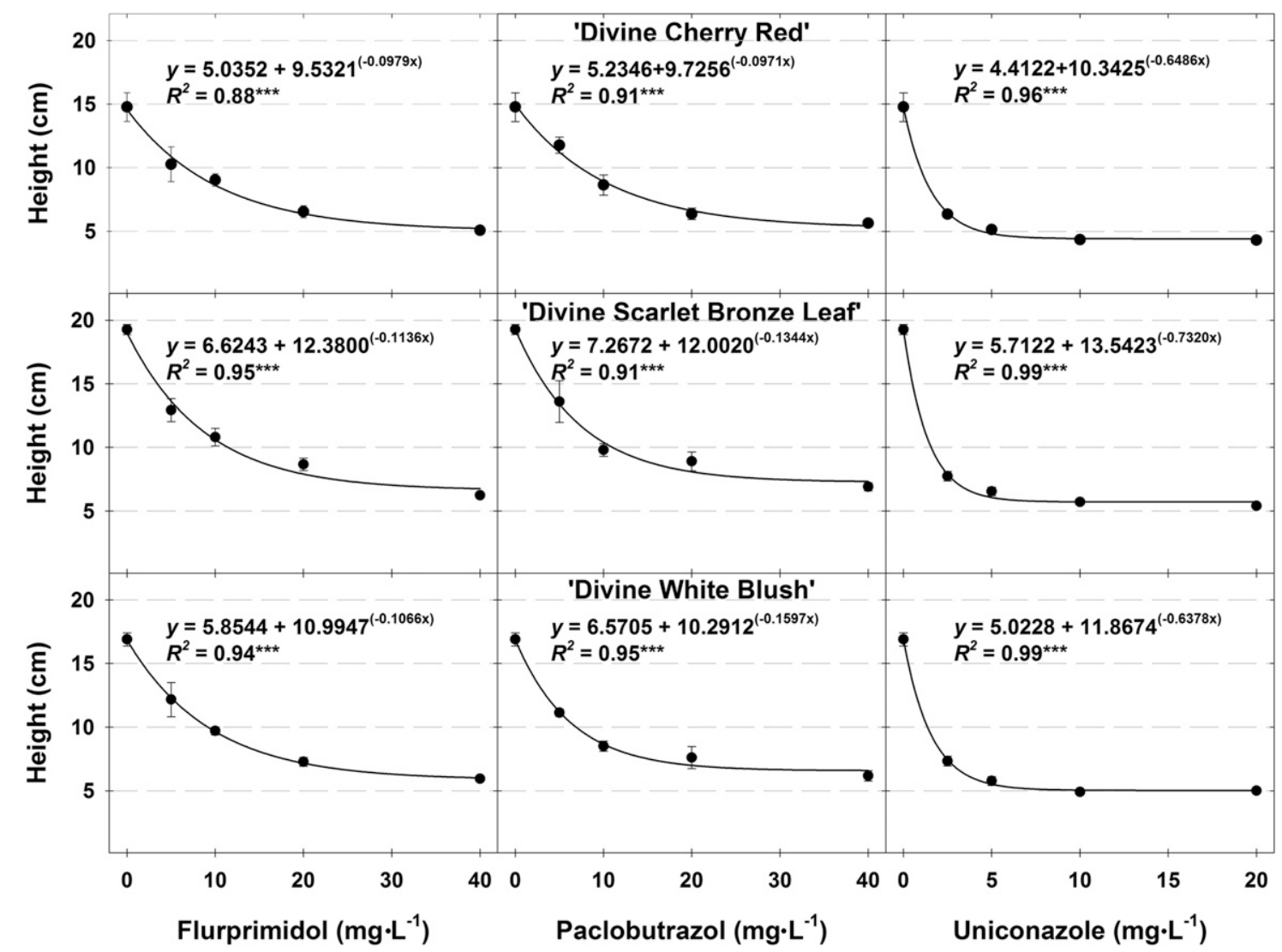

Fig. 1. Height of 'Divine Cherry Red', 'Divine Scarlet Bronze Leaf', and 'Divine White Blush' new guinea impatiens treated with foliar spray applications of water or plant growth retardant solutions $7 \mathrm{~d}$ after planting seedlings individually into 1801 -cell packs (Expt. 2). Data were collected 7 weeks after planting; $1 \mathrm{mg} \cdot \mathrm{L}^{-1}=1 \mathrm{ppm}, 1 \mathrm{~cm}=0.3937$ inch.

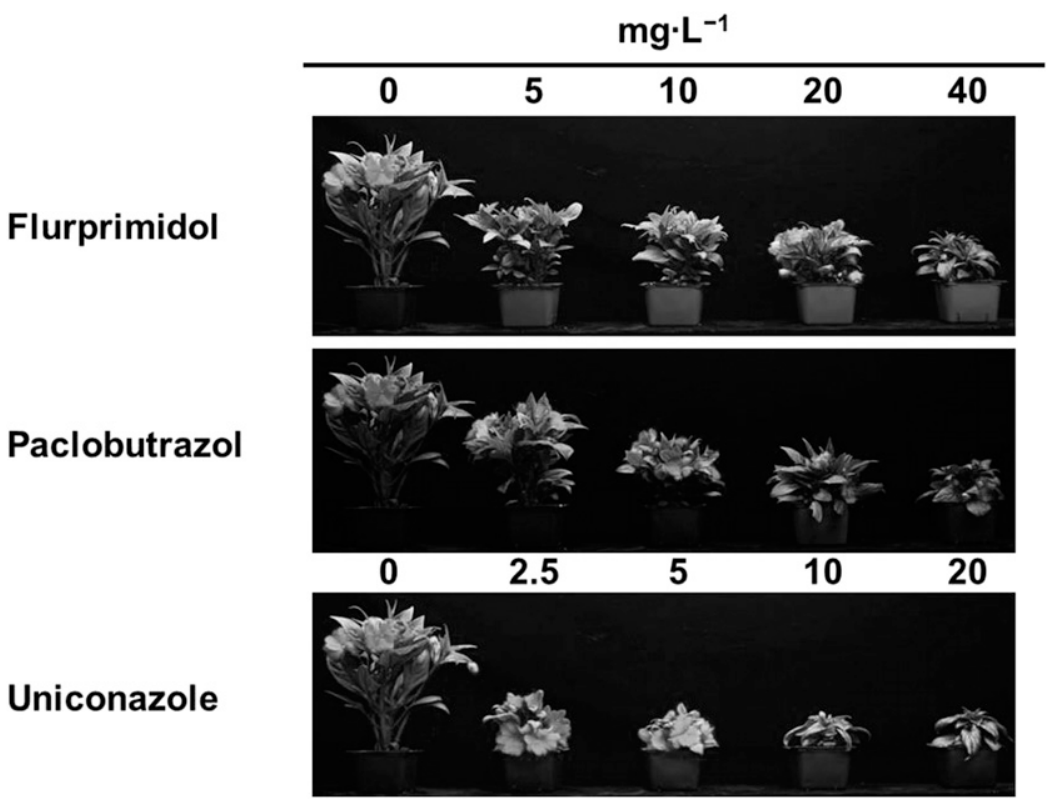

Fig. 2. 'Divine Cherry Red' new guinea impatiens treated with or plant growth retardant solutions $7 \mathrm{~d}$ after planting seedlings individually into 1801 -cell packs (Expt. 2). Photos were taken 7 weeks after planting; $1 \mathrm{mg} \cdot \mathrm{L}^{-1}=1 \mathrm{ppm}$.

chlormequat chloride, or daminozide applied as a foliar spray or substrate drenches containing chlormequat chloride on the growth of four different cultivars of new guinea impatiens. The authors report that, while some statistical differences in plant height were observed, these chemicals were not effective enough for use in commercial production. Although ancymidol was the most effective chemical used in their experiments, the concentrations used in their experiments were more than twice the concentrations included in our experiment. Our results on the effect of daminozide on controlling growth of new guinea impatiens conflict with those of McKnight and Klingaman (1990), but agree with Keever and Foster (1991). McKnight and Kilngaman (1990) report that, across 18 different cultivars, applying two foliar sprays of $2500 \mathrm{mg} \cdot \mathrm{L}^{-1}$ daminozide suppressed growth by $\approx 30 \%$ compared with untreated plants. Alternatively, Keever and Foster (1991), report that height of 'Zenith' new guinea impatiens treated with foliar sprays containing $5000 \mathrm{mg} \cdot \mathrm{L}^{-1}$ daminozide were 20.2 and $20.6 \mathrm{~cm}$ for untreated plants. Ancymidol, chlormequat chloride, and daminozide did not provide height control for the new guinea impatiens cultivars used in our study. One of the 


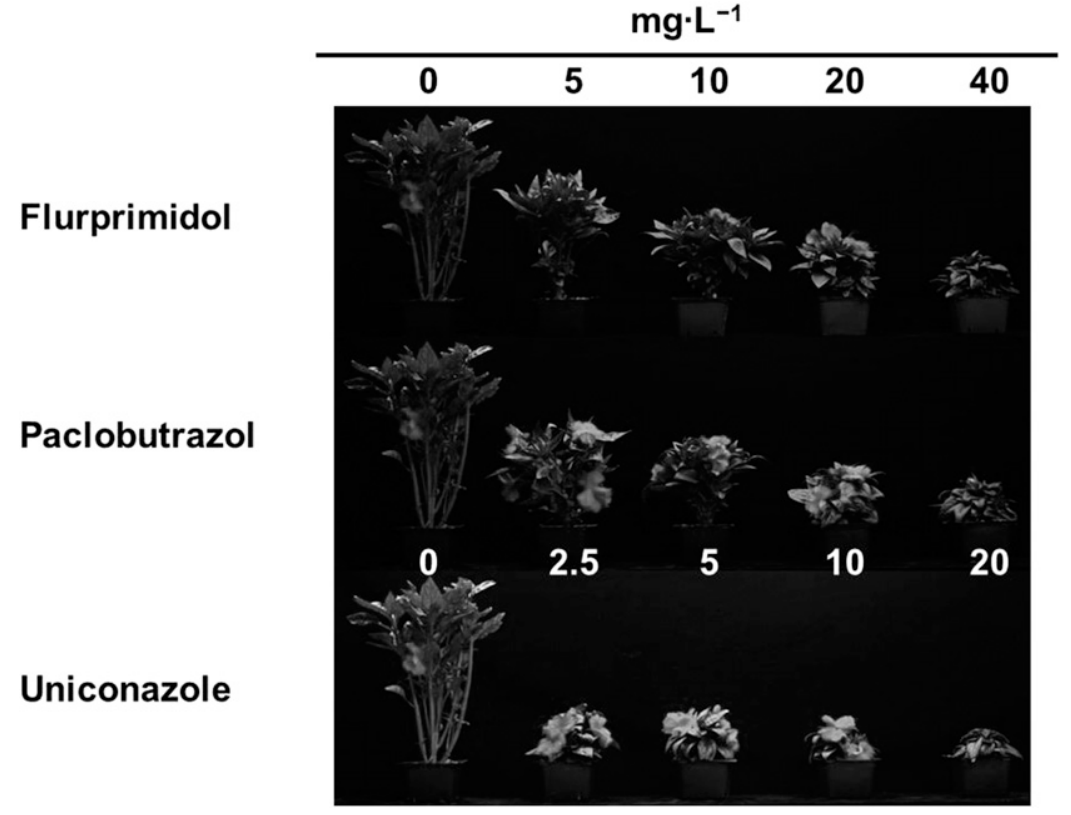

Fig. 3. 'Divine Scarlet Bronze Leaf' new guinea impatiens treated with or plant growth retardant solutions $7 \mathrm{~d}$ after planting seedlings individually into 1801 -cell packs (Expt. 2). Photos were taken 7 weeks after planting; $1 \mathrm{mg} \cdot \mathrm{L}^{-1}=1 \mathrm{ppm}$.

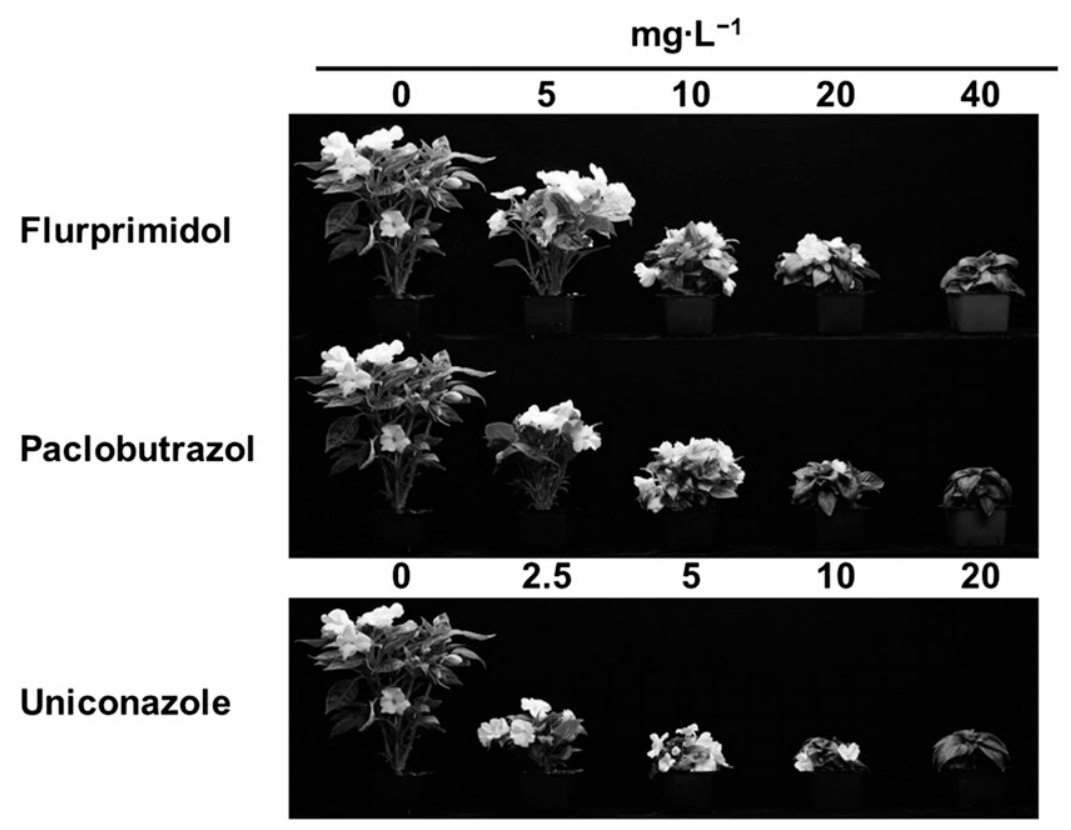

Fig. 4. 'Divine White Blush' new guinea impatiens treated with or plant growth retardant solutions $7 \mathrm{~d}$ after planting seedlings individually into 1801 -cell packs (Expt. 2). Photos were taken seven 7 weeks after planting; $1 \mathrm{mg} \cdot \mathrm{L}^{-1}=1 \mathrm{ppm}$.

reasons that may have contributed to the lack of effect on final plant height is that a single application was made. Multiple applications of chlormequat chloride or daminozide during crop production is not uncommon and may suppress height of see propagated new guinea impatiens; however, we wanted to focus on PGR applications that would successfully control height with a single application and minimize labor.

In our study we found flurprimidol, paclobutrazol, and uniconazole to be the most effective active ingredient in suppressing plant height when applied to new guinea impatiens, agreeing with previous reports using vegetatively propagated new guinea impatiens (Keever and Foster,
1991; Whipker et al., 2004a, 2004b). Uniconazole was also found to be effective at suppressing the size of seed-propagated 'Zenith' new guinea impatiens grown in 0.4- $\mathrm{L}$ containers (Keever and Foster, 1991). As the concentration of uniconazole increased from 1 to $30 \mathrm{mg} \cdot \mathrm{L}^{-1}$, plants were $7 \%$ to $45 \%$ shorter than untreated plants. Whipker et al. (2004a) quantified the efficacy of flurprimidol ( 5 to $\left.80 \mathrm{mg} \cdot \mathrm{L}^{-1}\right)$, uniconazole $\left(5 \mathrm{mg} \cdot \mathrm{L}^{-1}\right)$, and paclobutrazol $\left(10 \mathrm{mg} \cdot \mathrm{L}^{-1}\right)$ sprays on controlling growth of 'Pure Beauty Fuchsia' new guinea impatiens. The authors reported that applying either $10 \mathrm{mg} \cdot \mathrm{L}^{-1}$ flurprimidol or $5 \mathrm{mg} \cdot \mathrm{L}^{-1}$ uniconazole resulted in the best control of plant growth relative to the container size. In a subsequent study, Whipker et al. (2004b) treated eight different new guinea impatiens cultivars with 5 to $20 \mathrm{mg} \cdot \mathrm{L}^{-1}$ foliar sprays of flurprimidol. Plant height and diameter were $>20 \%$ smaller for at least five and six, respectively, of the eight cultivars when $10 \mathrm{mg} \cdot \mathrm{L}^{-1}$ flurprimidol was applied. The authors recommended that 5-10 $\mathrm{mg} \cdot \mathrm{L}^{-1}$ flurprimidol were useful concentrations to use for commercial production. While our results and subsequent recommendations for flurprimidol and paclobutrazol agree with much of the previous research with vegetatively propagated cultivars, the seed-propagated cultivars used in our experiment were more sensitive to uniconazole. We observed saturation in suppression of plant height at concentrations (4 to $5 \mathrm{mg} \cdot \mathrm{L}^{-1}$ ) similar to concentrations observed in earlier studies (Keever and Foster, 1991; Whipker et al., 2004a).

There are several reasons why flurprimidol, paclobutrazol, and uniconazole had the greatest activity in our research. These three PGRs are closely related chemicals (Rademacher, 2000). These active ingredients are generally considered to have the greatest efficacy and effectiveness among the different plant growth-retarding active ingredients (Barrett, 2001). Another potential explanation for the increased efficacy of these active ingredients is related to uptake, as all three are absorbed through shoots and roots. Therefore, solution landing on the substrate had the potential to further suppress growth.

We observed some negative effects on growth and flowering of new 
guinea impatiens resulting from foliar sprays of some of the PGRs. For instance, flowering of 'Divine Scarlet Bronze Leaf' treated with 500 or $1000 \mathrm{mg} \cdot \mathrm{L}^{-1}$ ethephon in Expt. 1 was delayed. Ethephon is an ethylenegenerating chemical and applications can cause a delay in flowering, in addition to suppressing stem elongation (Barrett, 2001). Walker and Harkess (1996) reported that foliar sprays containing $250 \mathrm{mg} \cdot \mathrm{L}^{-1}$ ethephon delayed flowering of 'Shadow' new guinea impatiens. Flowering was also delayed in both experiments when the highest concentrations of flurprimidol and uniconazole were applied. McKnight and Klingaman (1990) reported that flurprimidol and uniconazole both delayed flowering of new guinea impatiens by up to 2 weeks. Similarly, flowering of 'Pure Beauty Fuchsia' new guinea impatiens was delayed when foliar sprays of $5-80 \mathrm{mg} \cdot \mathrm{L}^{-1}$ flurprimidol, $10 \mathrm{mg} \cdot \mathrm{L}^{-1}$ paclobutrazol, or $5 \mathrm{mg} \cdot \mathrm{L}^{-1}$ uniconazole were applied (Whipker et al., 2004a).

In addition to some delay in flowering, phytotoxicity was observed. In Expt. l, some plants treated with chlormequat chloride exhibited chlorosis on leaves. Corr (1995) also reported that foliage of 'Spectra' new guinea impatiens exhibited marginal chlorosis following treatment with chlormequat chloride solutions greater than $750 \mathrm{mg} \cdot \mathrm{L}^{-1}$. While not phytotoxicity per se, the highest concentrations of flurprimidol, paclobutrazol, and uniconazole produced extremely stunted plants from overregulation of growth. For all three PGRs in Expt. 2, the highest concentration of each active ingredient was above the concentrations where suppression of growth is saturated.

To compare the costs of applying these different PGRs, we estimated the cost of applying flurprimidol, paclobutrazol, and uniconazole at the concentrations we identified as effective in this study using PGRCALC (Krug and Whipker, 2010). The cost of applying 5 to $10 \mathrm{mg} \cdot \mathrm{L}^{-1}$ flurprimidol or paclobutrazol, or 1 to $2.5 \mathrm{mg} \cdot \mathrm{L}^{-1}$ uniconazole is $\$ 2.76$ to $\$ 5.53, \$ 3.01$ to
$\$ 6.02$, or $\$ 3.51$ to $\$ 8.77$ per $1000 \mathrm{ft}^{2}$, respectively, with an application rate of $2 \mathrm{qt} / 100 \mathrm{ft}^{2}$. Since the costs of these treatments are fairly similar, the decision of which chemical to select may not be based solely on price of treatment. For example, producers may not select uniconazole because the risk of over application may be greater due to the greater active ingredient activity (Barrett, 2001).

The 'Divine' series of seedpropagated new guinea impatiens is a potential option for production in flats. Our research shows that solutions containing 5 to $10 \mathrm{mg} \cdot \mathrm{L}^{-1}$ flurprimidol or paclobutrazol or less than $2.5 \mathrm{mg} \cdot \mathrm{L}^{-1}$ uniconazole would be useful concentrations for suppressing height, so plants are appropriately sized within the flats. Although these concentrations provided acceptable results in our studies, results will vary with producer. Always perform inhouse trials with PGRs to see which concentrations work in your specific growing environment and cultural practices.

\section{Literature cited}

Armitage, A.M. 2001. Armitage's manual of annuals, biennials, and half-hardy perennials. Timber Press, Portland, OR.

Barrett, J.E. 2001. Mechanisms of action, p. 32-41. In: M.L. Gaston, P.S. Konjoian, L.A. Kunkle, and M.F. Wilt (eds.). Tips on regulating growth of floriculture crops. OFA Serv., Columbus, OH.

Caitlin, N. 2012. Alternatives to garden impatiens. 15 Sept. 2015. <https:// extension.umass.edu/floriculture/sites/ floriculture/files/pdf-doc-ppt/Alternativesto-Garden-ImpatiensCornell.pdfs .

Caitlin, N. 2013. Impatiens downy mildew—a review. e-GRO Alert 2(6): 1-4.

Corr, B. 1995. Seed new guinea impatiensseed to plug to finish, p. 105-111. In: W. Banner and M. Klopmeyer (eds.). New guinea impatiens: A ball guide. Ball Publ., Batavia, IL.

Dole, J.M. and H.F. Wilkins. 2005 Floriculture: Principles and species. 2nd ed. Pearson Prentice Hall, Upper Saddle River, NJ.
Haver, D.L. and U.K. Schuch. 1996. Production and postproduction performance of new guinea impatiens cultivars grown with controlled-release fertilizer and no leaching. J. Amer. Soc. Hort. Sci. $121: 820-825$.

Keever, G.J. and W.J. Foster. 1991. Production and postproduction performance of uniconazole-treated bedding plants. J. Environ. Hort. 9:203-206.

Krug, B. and B. Whipker. 2010. Using the PGR calculator. Greenhouse Grower 28(9):44-45.

McKnight, J.P. and G.L. Klingaman. 1990. The effects of growth and flowering, branching patterns and growth of new guinea impatiens. HortScience 25:1099 (Abstr.).

Nau, J. 2011. Ball redbook, Vol. 2: Crop production. 18th ed. Ball Publ., West Chicago, IL.

Pasutti, D.W. and J.L. Weigle. 1980. Growth-regulator effects on new guinea impatiens hybrids. Sci. Hort. 12:293-298.

Rademacher, W. 2000. Growth retardants: Effects on gibberellin biosynthesis and other metabolic pathways. Annu. Rev. Plant Physiol. Plant Mol. Biol. 51:501-531.

Still, S.M. 1993. Manual of herbaceous ornamental plants. Stipes Publ., Champaign, IL.

Walker, S.L. and R.L. Harkess. 1996. Delaying flowering using ethephon during new guinea impatiens production. HortScience 31:700 (Abstr.).

Warfield, C.Y. 2012. Downy mildew of impatiens. GrowerTalks 75(9):78-79.

Whealy, C.A. 1995. Commercial varieties, p. 213-226. In: W. Banner and M. Klopmeyer (eds.). New guinea impatiens: A ball guide. Ball Publ., Batavia, IL.

Whipker, B.E., I. McCall, J.L. Gibson, and T.J. Cavins. 2004a. Flurprimidol sprays control growth of new guinea impatiens. Plant Growth Regulat. Soc. Amer. Qrtly 32(1):4-8.

Whipker, B.E., I. McCall, B.A. Krug, and J.L. Gibson. 2004b. Flurprimidol foliar sprays control growth of eight new guinea impatiens (Impatiens hawkeri) cultivars. Proc. Plant Growth Regulat. Soc. Amer. 30:132-134. 